\title{
Consolidation / Resistance to Democracy in Shakespeare's Coriolanus (1607) and Rashad Rushdy's O, My Beloved Country(1968)
}

\author{
Amal Aly MAZHAR \\ Cairo University
}

Let me begin by the words of the philosopher Santyana "Those who do not learn from history will most inevitably repeat the same mistakes again" since this paper is concerned with the repetitive, eternal conflict in different ages between democracy and autocracy inevitably leading to traumatic consequences. The objective of the proposed paper is doublefold; to explore the timeless conflict between democracy and autocracy as represented in two highly important historical, political icons who had their significant roles in the fates of their respective countries, Coriolanus in ancient Rome and El Badawy in $12^{\text {th }}$ century Egypt. Political thinkers on dictators and dictatorship contend that there are certain paradigms which can apply to dictators or autocrats and the making of dictators. Thus the paper will explore the depiction of a would-be autocrat in Coriolanus who seeks to consolidate aristocratic oligarchy, and the contrary representation of the spiritual leader, El Sayed el Badawy whose disciples and followers seek to create of him an infallible, unimpeachable spiritual leader, subtly implying "spiritual absolutism", in O, My Beloved Country! but, ironically, he is the one who seeks to subvert it. Secondly, to explore the implicit projection of these historical figures on $17^{\text {th }}$ Jacobean England, and a post1967 Egypt political scene.

My reading of the two plays is inspired by the tenets of New Historicism and Cultural Materialism which observe "the historicity of the text and the textuality of history" (Montrose, 20) as renowned New Historicist critic Louis Montrose succinctly puts it, that which places the 


\section{Consolidation / Resistance to Democracy in Shakespeare \& Rushdy}

literary text within the frame of non-literary texts . This method focuses on the way literature and drama express, and sometimes disguise power relations at work at the time in which the text was produced, often this involves making connections between a text and other kinds of texts. By adopting this method the paper seeks to show that these highly significant historical icons are not temporally bound signs, and are not depicted as ends in themselves ,but are rather manipulated as projections on political, intellectual, social, cultural ...etc conditions in a Jacobean, postElizabethan age (which witnessed the first popular English revolution) and a post-1967 defeat in Egypt and seek to convey implicit messages. My concern is not to trace the historical authenticity or veracity of these two dramatic figures against their real historical figures, but rather to inquire how the two dramatists manipulated them to convey their implicit political messages. This is corroborated by the fact that the two dramatists reveal an amazing knowledge of political structures at work in their time, and dramatized them.

Significantly, Shakespeare's concern with antiquity was manifested in five plays in the later stage of his dramatic career (1602-1608)after the death of his patron queen Elizabeth and the ascension of James I to the throne, in which the question of democracy occupies central position. Thus, if we consider "the relation in which the text was produced" in order to decode the underlying message, we will notice that the choice of the despotic Roman consul Coriolanus in particular at this historical juncture is not random or haphazard. The paradox underlying Shakespeare's Coriolanus is that in Coriolanus' time, Rome was a Republic ,yet the oligarchic institution of the Roman Senate posed a real threat to this republican system. ${ }^{1}$ The play is mainly concerned with the dramatization of the conflict between the advocates of democratic rule that observes the needs of the plebeians and the opposite pole representing the interests of the oligarchic system of the Roman Senate. Shakespeare masterfully depicts the character of the dictator who defies democratic rule as opposed to the 


\section{Amal Aly MAZHAR}

power of the people in consolidating democracy. This is done from the very opening scene when Menenius, the signifier of the oligarchic aristocracy cynically rebukes the citizens for their rebellion against social injustice, in which they call for fair distribution of corn, social justice and the correction of political corruption where the rich become richer and the poor die of starvation, where acts of law and statutes are made for the benefit of those in power. Responding on behalf of the plebeians who are downtrodden by the patricians, the anonymous First Citizen utters words to express the people's grievances which encapsulate the violations of a corrupt oligarchic regime, albeit disguised under a democratic, republican system. Strangely, the words are highly applicable to ancient Rome, Jacobean England, or for that matter,21st century Egypt!

The First Citizen: They ne'er

Car'd for us yet. Suffer us to famish, and their

Store-houses cramm'd with grain; makes edicts for Usury, to support usurers; repeal daily any wholesome

Act establish'd against the rich, and provide more

Piercing statutes daily to chain up and restrain the

Poor. If the wars eat us not up, they will; and there's

All the love they bear us. (ActI,sci, 79-86)

The plebeians' social protest which resists violations of human rights, is satirized and met by Menenius' further disdain who toys with the plebs' emotions in an attempt to consolidate an undemocratic rule which ironically defies the chosen republican system of government. The trenchant paradox is revealed with the following words "The Roman mob is in need of governance... at this time Rome was a republic, although power was still in the hands of a few aristocrats." (Cahn, 242) Menenius seeks to curb the voice of rebellion and social discontent "he offers in contrast the voice of aristocracy, self-satisfied and eager to maintain the status quo" (Cahn,243).In a further attempt to play down their rebellion and call for a fair share of the nation's wealth, the rich and conservative patrician senator Menenius adopts a haughty, superior tone which further aggravates the 


\section{Consolidation / Resistance to Democracy in Shakespeare \& Rushdy}

violation of the people's dignity by referring to one of the play's central figurative motifs in the analogy of the body politic in the famous belly speech in which the state represents an organic body in which different classes or vocations of citizens are parts or members, while the aristocrats represent the "belly" while the downtrodden, lower classes represent the "toe" in an attempt to justify, legalize and consolidate the unlimited privileges for the ruling class patricians when he makes the analogy "The senators of Rome are this good belly,/And you the mutinous members..." (ActI,sci148-149), concluding with a vile analogy of the head of this popular revolutionaries, The First Citizen, as "the great toe of this assembly" (ActI,sci,155).

Thus, the autocratic tendency which defies the chosen Roman republican system of government is explicitly spelled out and evoked, constituting the most convenient atmosphere for the emergence of Coriolanus, the iconic figure representing the arrogance of autocracy.

Thus, it is highly significant that upon his first appearance, Coriolanus as the patrician who seeks to consolidate autocracy would adopt a strategy of demeaning and disdaining the plebs as the "underdogs".

Coriolanus: What's the matter, you dissentious rogues, That rubbing the poor itch of your opinion Make yourselves scabs?(I,I,164-166)

In a highly disdainful note, Coriolanus rebukes their call for democracy when he continues his mockery of certain political representatives by using a derogatory animal imagery:

Coriolanus: He that give good words to thee will flatter

Beneath abhorring. What would you have you curs,

That like nor peace nor war? The one affrights you,

The other makes you proud. He that trusts to you,

Where he should find you lions, finds you hares; (I,I,167-171)

Commenting on the opening scene, Cohen and Weimann declare that it 


\section{Amal Aly MAZHAR}

pits the oppressed plebeians against the Roman senators, who make edicts for usury,to support usurers; repeal daily any wholesome act established against the rich, and provide more piercing statutes daily to chain up and restrain the poor .Coriolanus, both the noblest and the most arrogant member of the aristocracy, lives and dies in relation to this struggle.

(Cohen and Weimann,9)

The derogatory, demeaning discourse used by Coriolanus when he talks about, or to the plebs, is a consistent strategy to violate the basic tenets of democracy of the human rights of the people to be treated respectfully and on equal footing. Though Coriolanus' military bravery won him the much acclaimed title of a national hero, it is nonetheless counterpoised by this negative quality .Even the people, under whose name Coriolanus won these wars defy and challenge the consolidation of autocracy when the Fourth Citizen confronts him "You have been a scourge to your enemies, you have been a rod to her friends. You have not indeed, loved the common people"(Act II,sciii,lines91-93).Coriolanus' aversion and despise of the people indicates too clearly his negligence of them as human beings and consequently of their real demands. This disdain is very frequently manifested in his reference to their bad smells(Acts I,II, and III).At one point he satirizes the plebs by saying "I crave their pardons/For the mutable rank-scented meinie"(Act III,sci,lines69-70)Even at such important moments when he seeks consulship he tells Menenius "Bid them wash their faces/And keep their teeth clean" (ActII,sciii,62-63).Coriolanus discloses his real undemocratic nature when he asks the representatives of the people(the tribunes) and the senators "that love the fundamental part of state/More than you doubt the change on't, that prefer/to jump a body with a dangerous physic" (Act III,sci,lines154-157) therefore "...at once pluck out/The multitudinous tongue; let them not lick/The sweet which is their poison" (ActIII,sci,lines158-160).His disdain of the people is escalated in the fight between him and the people when he compares them to fatal and deadly diseases 


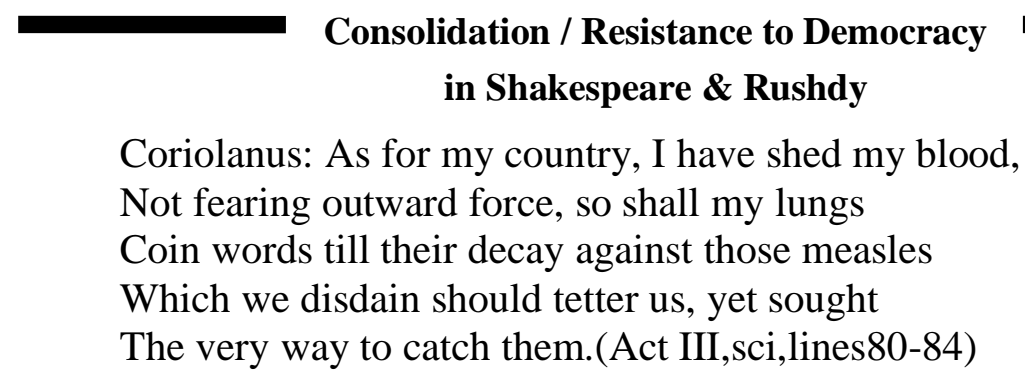

When the people are insulted by being called deadly and fatal diseases, the people's tribune Brutus, comes into full conviction that Coriolanus' stance and transgression is unpardonable "You speak o' th people as if you were a God/To punish, not a man of their infirmity"(ActIII,sci,lines85-86)

Despite his deeply engrafted disdain of the people, he nevertheless seeks their support to become the elected consul in accordance with the rules of the republican system. Coriolanus' inflated self-image makes him unable to perceive himself as deriving his powers and status from the people .Observed Roman rules of democracy stipulated that a future consul would put on the garment of humility and request modestly the people's approval. Though Coriolanus performs these mandatory procedures merely as tactical steps, not as a true conviction, his reluctance and disbelief in them are conspicuous. He entreats Menenius and the people's tribune Sicenius

Coriolanus: I do beseech you, Let me o'erleap that custom, for I cannot

Put on the gown, stand naked, and entreat them

For my wounds' sake to give their suffrage.

Please you that I may pass this doing. (Act II,sc,ii,lines137-139)

Yet, under the force of these republican rules he cynically tells the Citizens “...'twas never my desire yet to trouble the poor with begging"(ActII,sciii,lines69-70)

Yet, after getting their voices, he regrets, in a cynical tone that he had to comply with the observed Republican rules of democracy 


\section{Amal Aly MAZHAR}

\section{(Exeunt Citizens)}

Coriolanus: Most sweet voices.

Better it is to die, better to starve,

Than crave the hire which first we do deserve.

Why in this womanish toge should I stand here

To beg of Hob and Dick that does appear

Their needless vouches? Custom calls me to't

What custom wills, in all things should we do't.

(Act II,sciii,lines112-119)

Coriolanus as signifier of absolutism and defiance of Republican

\section{Democracy:}

Despite Coriolanus' tactical step of feigning modesty to become consul, his true anti-republican sentiments surface and become undeniably evident. Probably ,the most telling and succinct epithet to describe him are the words said by his mother Volumnia to reprimand him "You are too absolute"(ActIII,scii,line40)when he rejects her exhortation to return to the tribunes and repent for his disdain of the people. Significantly, the autocratic, despotic mentality of the would-be consul lacks in political insight as Volumnia exhorts him to combine "honour and policy" in peace as well as in war. Extreme lack of political discretion, dictated by his autocratic mentality is discerned in his total negation of the people, the senators' advice or even the Gods, when Coriolanus admits he cannot return to the tribunes and repent for his insulting transgressions of the people. He arrogantly declares "For them? I cannot do it to the Gods/Must I then do it to them?" (ActIII ,scii, lines38-39)

Coriolanus unravels his true personality as dictator in the inevitable confrontation between him and the people's tribunes. In the climactic act three, the clash between democracy and autocracy rises to the surface. Though Cominius, Coriolanus' aide intervenes and tries to thwart him, Coriolanus' unrestrained ambitions defy and clash with the true democratic sentiments of the Romans who opted for democracy. Cominius succinctly puts in a nutshell Coriolanus' autocratic behavior versus the democratic 
Consolidation / Resistance to Democracy in Shakespeare \& Rushdy

Roman system of government "The people are abused, set on/This plat'ring/Becomes not Rome" (ActIII,sci,lines62-64)

In resisting democracy, Coriolanus makes it clear that he does not only defend his own personal interests and ambitions, but the interests of the privileged oligarchic system as well to which he belongs. In what could be called a counter revolution, he instigates the privileged senators and oligarchic system to resist the people's will. Ironically, he calls the people's calling for their rights, a subversion of the chosen system of government.

He instigates the senators to defend their rights

Coriolanus: In soothing them[the plebs] we nourish 'gainst our

Senate

The cockle of rebellion, insolence, sedition,

Which we ourselves have ploughed for, sowed and scattered

By mingling them with us, the honoured number

Who lack not virtue, no, nor power, but that

Which they have given to beggars. (ActIII,sci,lines73-78)

The rejection of the people's will who form a majority is shown in the clash in the climactic scene .Having insulted the plebs, Coriolanus culminates his self-defense that the senate will not give in to the people's demands. He cynically mimics the people by saying:

Coriolanus: 'We [the people] did request it,

We are the greater poll, and in true fear

They [the senate] gave us our demands' (ActIII,sci,line136-138)

These are the demands of the people who form a majority which Coriolanus explicitly defies and rejects. He interprets this as a display of the people's tyrannical power, shows his true nature as one who advocates an undemocratic counter-revolution, under the false pretext that it is a debasement of the elite senator's authority.

Coriolanus:

Thus we debase

The nature of our seats, and make the rabble

Call our cares fears which will in time

Break ope the locks o'th' senate and bring in

The crows to peck the eagles. (ActIII,sci,138-142) 


\section{Amal Aly MAZHAR}

Coriolanus upholds and seeks to perpetrate the prerogatives of the elite oligarchic minority over the majority of the plebs, in a clear subversion of the basic tenets of democracy. He is supported in that by Menenius and Cominius, two characters who represent the oligarchy.

In Defense of Republican democracy: The Tribunes of the people:

Standing at opposite end of the autocratic oligarchic system which seeks to establish itself further are the tribunes of the people, or in other words representatives of the people who defend their interests against those who threaten a democratically-elected system of government. In a highly significant utterance, Sicinius, urging the people to mutiny against the undemocratic consul asks the people "What is the city but the people?" to which all the Citizens respond "The people are the city!" (Act III,sci,lines197-199). It is only logical that Coriolanus, representing the interests of the oligarchy would be disdainful of the tribunes and discloses his hatred of the spirit of democracy represented in the two tribunes-Brutus and Sicinius. Fully conscious of their functional roles as defenders of democracy, and hence they could threaten and jeopardize his interests as well as that of his class, he sneers at them by saying:

Coriolanus: Behold, these are the tribunes of the people

The tongues o' th' common mouth. I do despise them

For they do prank them in authority

Against all noble sufferance. (ActIII,sci,lines22-25)

By contrast to Coriolanus, Brutus, as one of the people's tribunes is aware that his authority is derived from the people. In a threatening tone, he warns Coriolanus that "By the consent of all/We were established the people's magistrates."(Act III, sci, lines 200-201)and hence by the democratically-invested power in them ,he declares 'Upon the part o'th' people in whose power/We were elected theirs, Martius is worthy/Of present death." (ActIII, sci, lines 209-211).Thus, the Citizens becoming aware of the tribunes' enlightening role, declare on the tongue of the First 


\section{Consolidation / Resistance to Democracy}

in Shakespeare \& Rushdy

Citizen : "The noble tribunes are the people's mouths/And we are their hands."(Act III, sci, lines 271-272). Thus, the patrician Menenius humorously and cynically calls them "the herdsmen of the beastly plebeian" (ActII,sc,I,line93). Despite Coriolanus' military courage which invests Rome with glory and wealth, they, as magistrates, or representatives of the people are apprehensive of Coriolanus' tendencies towards autocracy which later proves be true and indicates their political insight.

Sicinius: I heard him swear,

Were he to stand for consul, never would he

Appear i'th' market-place nor on him put

The napless vesture of humility,

Nor, showing, as the manner is, his wounds

His wounds to th 'people, beg their stinking breaths.

(Act II, sc I,line228-233)

This political insight proves to be correct, when they show their concern and apprehension of Coriolanus' future behavior and manipulation of the people. Brutus warns Sicinius: "You see how he intends to use the people?'(ActII,scii,line156).

In seeking to consolidate democracy, Shakespeare shows how the people's representatives must overlook their personal interests. The two tribunes play an enlightening role in guiding the people to make the right choice and to eradicate their ignorance in the face of the manipulation of the oligarchic system, represented in Coriolanus. After being manipulated by Coriolanus to be elected consul, the two people's tribunes go to the extreme measure of self-denial by urging the people to lay the blame of their wrong elections on them and consequently ask them to revoke their choice.

Sicinius(to the Citizens): $\quad$ Say you chose him

More after our commandment than as guided

By your own true affections, and that your minds,

Preoccupied with what you rather must do

Than what you should, made you against the grain

To voice him consul. Lay the fault on us. (ActIII,sci,lines29-34) 


\section{Amal Aly MAZHAR}

They bluntly ask them to revoke their election of an undemocratic consul on the grounds that they were cheated or ill-advised, and having done so they move to a further step of instigating them to mutiny. Sicinius, talking on behalf of the people warns them against Coriolanus' Machiavellian manipulation "You are point[sic!] to lose your liberties. / Martius would have all from you."(ActIII,sci,lines194-195).Being alerted to the threat posed by Coriolanus' undemocratic behavior, the First Citizen's words indicate too clearly the political role of both the tribunes in guiding and instigating the people, and these latter's role in implementing their instructions "He [Coriolanus] shall well know/The noble tribunes are the people's mouths/And we their hands." (ActIII,sci,lines270-272) .Answering Coriolanus' question of why he was so dishonoured in taking the consulship after he was given it, Sicinius clearly shows that he is defending the democratic system of government against the tyrannical behavior of Coriolanus.

Sicinius: We charge you that you have contrived to take

From Rome all seasoned office, and to wind

Yourself into a power tyrannical,

For which you are a traitor to the people.(ActIII,sciii,66-69)

The clash between the people's tribunes and Coriolanus, or the conflict between the consolidation of democracy and its subversion, reaches an absurdist climax when Coriolanus covets the tribunes' position in defending the people's rights! The situation reaches an absurd climax when he cynically asks the tribunes "Make me your fellow tribune." Sicinius discloses the absurdity of the situation by pointing out that the violator of democracy is the same person who is now asking for its consolidation "You show too much of that/For what the people stir" (ActIII,sci,line55-56).

The vigilant role played by the people's representatives in preserving the people's rights can be discerned in terminating the dehumanizing treatment of the people and their enslavement. This is evident when they pass a verdict either of physical punishment on Coriolanus or banishment. Despite his military achievements for Rome for which he was honoured, as 


\section{Consolidation / Resistance to Democracy}

in Shakespeare \& Rushdy

Brutus says "When he did love his country/It honoured him" (ActIII, scii, lines 306-307), his dehumanizing, autocratic behavior towards the people negates and denies him this superior status. The verdict which is passed against his autocratic behavior compares it to a deadly illness which has to be amputated "The service of the foot,/Being once gangerened, is not then respected/For what before it was."(ActIII,scii,lines 308-310).

However, it is very interesting to note that Shakespeare clearly alludes to the tyrannical power which could be played by the people's representatives ,or in our modern terminology "the tyranny of the majority" .Sicinius shows himself to be a most tyrannical tribune of the people. In a long speech, he monopolizes speech, passes judgment on Coriolanus' punishment either by being thrown from a rock or by his banishment(Act III,sciii,lines99-109),concluding in the very decisive tone "I'th'people's name /I say it shall be so" (line 109). When Cominius, the former consul, intervenes on Coriolanus' behalf, Sicinius cuts him short by saying "he's sentenced. No more hearing" (Act III,sciii,line113), and "We know your drift. Speak what?" in answer to Cominius' pleading "Then if I would /Speak that..." (line119).The people's tribunes are guilty of using underhand means of procuring people's voices. Sicinus bluntly asks "Have you a catalogue/Of all the voices that we have procured/Set down by th' poll?" (Act III,sciii,lines7-9). These underhand means involve using demagogic methods to instigate the people .Sicinius explicitly orders them

Sicinius: Assemble presently the people hither,

And when they hear me say"It shall be so

I'th' right and strength o'the commons", be it either

For death,for fine, or banishment, then let them

If I say "Fine", cry "Fine!",if "Death", cry" Death"!(Act

iii,sciii,lines12-16)

Brutus, the other people's tribune also uses the same demagogic means

Brutus: And when such time they have begun to cry,

Let them not cease, but with a din confused

Enforce the present execution

Of what we chance to sentence.(Act III,sciii,lines19-22) 


\section{Amal Aly MAZHAR}

In order to reach their target they use uncivilzed method of arousing Coriolanus' wrath as proof of his tyranny. Brutus exhorts his followers "Put him to choler straight .../...Being once chafed, he cannot/Be reined again to temperance." (Act III,sciii,lines25-28).

The people are manipulated by the tribunes, which causes Menenius' critical rebuke of their passivity in driving away Coriolanus, their defender. Though Menenius expresses the voice of the elite oligarchy, his condemnation of the people's passivity indicates too clearly that they have been brainwashed by their tribunes, and are now acting like robots. Though the citizens attempt to defend themselves against these charges by claiming "When I said "banish him, I said "twas pity", and while the Third Citizen claims "And so did I, and to say the truth so did many very of us. That we did for the best, and though we willingly consented to his banishment, yet it was against our will." (ActIV scvii, lines 151-154) they all the more show that they have been brainwashed. Cominius' sarcastic rebuke of them enhances the notion of their being manipulated by their tribunes "Your goodly things, you voices." His reduction of these Citizens to mere voices manipulated by the tribunes incriminate the tribunes. Interestingly, the tribunes become aware that they have gained power after Coriolanus' banishment. Brutus' words "Now we have shown our power,/Let us seem humbler after it is done/Than when it was a-doing." (ActIV, scii, lines2-4). Shakespeare's political insight shows too clearly that the tribunes' act of humility is nothing but a disguise which could possibly point to them as signifiers of "the tyranny of the majority".

In this highly political play, Shakespeare makes it manifest that the tragic hero's responsibility is doublefold; it is not merely individual, but is brought about by the elitist oligarchic culture to defend the interests of this class. Despite his great military achievements in the name of Rome, his personal tragic flaws bring about his tragic doom .Even at the very moment of his triumph when he returns crowned with an oaken garland, emblematic of triumph, he cannot conceal his arrogance and disdain of the 


\section{Consolidation / Resistance to Democracy}

in Shakespeare \& Rushdy

plebs. He tells his mother Volumnia "I had rather be their servant in my way/Than sway with them in theirs." (ActII,sci, lines 200-201). His notion of serving Rome in his way though, does not mean to serve the Roman plebs. This accounts for the fact that in the Capitol, and after his triumphant return, two officers discuss his character "That's a brave fellow, but he's vengeance proud and loves not the common people." (ActII,scii,lines56).However, the most fatal tragic mistake is his alliance with Tullus Aufidius, the enemy of Rome whom he vanquished in the past, and conspiring against Rome. Thus the military hero, once denied absolute political power as consul by his countrymen, seeks to destroy his country. Coriolanus justifies this deprivation of an autocratic power as a revenge from his "thankless country" (line 71) and "for I will fight/Against my cankered country with the spleen/Of all the under-fiends." (Act IV, sc v, lines91-93).Thus, deprivation of absolute authority as an act of subversion of democracy is met by Coriolanus' self-destructive treachery. Denied absolute authority, Coriolanus turns into an enemy of his own people and country "My birthplace hate I, and my love's upon/This enemy town." (Act IV, sc v ,lines 23-24)

The role played by the elite oligarchy in Coriolanus'tragic fate:

Besides Coriolanus' individual responsibility, on account of his arrogance ,unrestrained ambitions and defiance of democracy in bringing about his tragic doom, Shakespeare makes it manifest that the elitist oligarchic culture plays a great role in it. The responsibility of the patricians, senators in authority, and the entourage enhance Coriolanus' clear inclination towards autocracy, and encourage him to seek to become an autocratic ruler whose disdain of the plebeians is always undeniably declared. Menenius, as a member of the privileged class, plays a role in subverting democracy in the act of dehumanization that Coriolanus engages in from the very outset of the play. Menenius' narration of the humourous anecdote in which he makes an analogy between the belly, i.e. the privileged senators of Rome and the plebeians as the disdained toe (Act I, 


\section{Amal Aly MAZHAR}

sci, lines 145-152) is done in order to pave the way and consolidate the notion of autocracy. Cominius, another patrician, plays his role in the consolidation of Coriolanus' dictatorship. Hyperbolic flattery of Coriolanus and the entourage of the hero eventually turn him into a seeker of absolute authority. After Coriolanus' victory over the Volscians, led by Tullus Aiufidius, Cominus hails him by further unleashing his arrogance ,by implying that he is not fully aware of his merits, which Cominius and the other patricians will force him to recognize.

\section{Cominius: Too modest are you,}

More cruel to your good report than grateful

To us that give you truly. By your patience, If 'gainst yourself you be incensed we'll put you, Like one that means his proper harm, in manacles, Then reason safely with you. (Act I,scx, lines53-57)

Cominius bluntly admits his role, together with all Coriolanus' entourage, in the making of an autocrat. Offering him the "war garland", emblematic of military victory, Cominius hyperbolically applauds him. This is further developed in his extremely long public speech to the Romans in which he applauds Coriolanus' feats at war from an early age which wins him the right for consulship when he urges them to transform the great military hero into a political figure, a consul. He begins his speech thus: "The deeds of Coriolanus/ Should not be uttered feebly."(Act II,scii,line82-83).Listing his feets at war, he claims that he does not covet any authority

Cominius: $\quad$ Our spoils he kicked at, And looked upon things precious as they were The common muck of the world. He covets less Than misery itself would give, rewards His deeds with doing them, and is content

To spend the time to end it.(ActII,scii,lines124-129) 


\section{Consolidation / Resistance to Democracy in Shakespeare \& Rushdy}

The struggle for the authority on behalf of the elite oligarchy is resumed after Coriolanus' banishment. The Roman Nicanor admits that the nobles ,incensed by Coriolanus' banishment seek to restore their authority, thus attempting a new round of undermining the democratic will of the people "for the nobles receive so to heart the banishment of that worthy Coriolanus that they are in a ripe aptness to take all power from the people, and to pluck from them their tribunes for ever." (Act IV,scii,lines19-22).

It is my contention that a New Historicist reading of the play would reveal the pertinence of depicting Coriolanus to project on similar conditions in Jacobean England of social injustice and undemocratic monarchial rule. The corn shortage in Roman times, leading to the people's rebellion due to the unjust distribution of the corn among the aristocracy and the plebs had its counterpart in Jacobean England. Cohen and Weimann point that

The plebeians [in the opening scene] may here be echoing the popular protests of 1607 ,in which Levellers and Diggers first appeared. Although Shakespeare hardly advocates the overthrow of patrician rule he at least shows the legitimacy of lower-class grievances (Cohen and Weimann,97)

Kristeva, Green and Adelman likewise reverberate the similar notion that

Coriolanus was written during a period of rising corn prices and the accompanying fear of famine; rising prices reached a climax in 1608. In a great number of common persons'-up to five thousand, Stow tells us in his Annales-assembled in various Midland counties, including Shakespeare's own county of Warwickshire, to protest the acceleration of enclosures and the resulting food shortage.(Kristeva, Green and Adelman, 354)

They further explain that

It must have been disturbing to property owners to hear that the rioters were well received by local inhabitants, who brought them food and shovels-doubly disturbing if they were aware that this was one of England's first purely popular riots, unlike 


\section{Amal Aly MAZHAR}

the riots of the preceding century in that the anger of the common people was not being manipulated by rebellious aristocrats or religious factions. Nor is Shakespeare's exacerbation of these fears merely a dramatist's trick to catch the attention of his audience from the start, or a seventeenth century nod toward political relevance.(354)

However, it is my contention that Shakespeare was lashing his implicit criticism of King James I's tendencies towards "royal absolutism". King James I, who ruled after the death of Shakespeare's patron, Queen Elizabeth I in 1603, is described to have "been a strong advocate of royal absolutism, and his conflicts with an increasingly assertive Parliament set the stage for the rebellion against his successor, Charles I" (Encyclopaedia Brittannica Online Inc.2012 Web,02Feb2012). He is also described as "when he started to govern[as Scottish king] for himself[after the deposing of his mother Mary Queen of Scots], he ruled through his favourites, which caused a rebellion and a period of imprisonment. On Elizabeth's death, he ascended the English throne... At first he was well received, [yet]his favouritism again brought him unpopularity." (The Cambridge Paperback Encyclopaedia, ed. Davis Crystal,1999,443). The implicit criticism of James' royal oligarchy or absolutism, to my contention, is reflected in Shakespeare's depiction of Coriolanus in1607, as the dramatic embodiment of King James himself ,after the most traumatic incident that faced James' rule, The Gunpowder plot which took place two years prior to the writing of Coriolannus.

A conspiracy by the Catholic gentry, led by Robert Catesby, to blow up the English Houses of Parliament. It failed when Guy Fawkes, who placed the explosives, was arrested(5th of November 1605).The scheme reflected Catholic desperation after the failure to remove James in 1603. (Cambridge Paperback Encyclopaedia, 375)

Ironically, king James I asserted his claims to be a democratic parliamentary king in an often cited passage from Basilikon Doron, as 


\section{Consolidation / Resistance to Democracy}

\section{in Shakespeare \& Rushdy}

Jonathan Dollimore aptly points out in which he likened the king to "one set on a stage, whose smallest actions, and gestures all the people gazingly do behold; [and] any 'dissolute' behavior on his part breeds contempt, the mother of rebellion and disorder"(Qtd by Dollimore, 8$)^{2}$. Ironically, his actions belie him as testified by his clash with the Parliament to secure more monarchial authority, or the Divine Rights of Kings. Tennenhouse aptly points out

James' first year and a half saw numerous complaints about the inefficiency of his bureaucracy and his misuse of what remained of feudal sources of revenue. Throughout his first parliament there were serious disagreements over who constituted the law, James claiming for himself the power to be the lex loquens while the Commons countered that he could only be the law speaking with the aid of a sitting Parliament. (Tenenenhouse,118-119)

The claim to observe democratic rule was manifested in the negotiations between him and the Parliament in 1609 in what was termed "The Great Contract", but as Tennenhouse aptly points out

After six weeks of debate it was clear that James' use of royal prerogatives, his notion of an absolute monarchy, and his notorious liberality all contributed to Parliamentary unwillingness to accept Cecil's proposals on behalf of the king. In his speech to Parliament on 21March1610 James tried to force Parliament into helping him solve his financial dilemma by redefining their refusal to do so as a violation of divine law.(Tennenhouse, 117)

To my belief, through Coriolanus, Shakespeare, was uncovering the monarchial absolutism of James I whose claims of parliamentary, democratic rule were blatantly belied by his own practices. Such monarchial absolutism which aggravated in James 1's successor, Charles 1,led to the first English bloody revolution and the beheading of Charles I in 1648 . 


\section{Amal Aly MAZHAR}

Written one year after the horrific 1967 defeat, Rashad Rushdy's $O, M y$ Beloved Country! (1968) interestingly dramatizes the conflict between the attempts at undemocratic practices by deifying the spiritual leader El Sayed Ahmed El Badawy, by the common man, interest groups, swindlers and corrupt entourage in order to reap and garner benefits and gains. Ironically, the resistance to such attempts are done, not by the people, but by El Badawy himself, as well as by the national hero Metwally "the Angry Revolutionary", as well as by the ageless, Tiresias -like figure El Mallawany who represents the "political unconscious" of the people. A sophist who lived in 12th century Egypt, in turbulent times which witnessed the threat of an external enemy, represented in a series of crusade campaigns, as well as internal strife among conflicting dynasties (the Ayyubids and the maritime Mamelukes) El Badawy never coveted any form of authority. I contend through a new historicist reading of the play, that Rushdy dramatized the conflict of democracy versus oligarchy in 12 thcentury Egypt not as an end in itself, but because it projected similar conditions in Egypt which were the causes of horrific, unprecedented 1967 defeat Egypt, as well as the means to redress them.

\section{Deification of the leader or the centralization of authority:}

Though El Sayed Ahmed El Badawy is not dramatized as the sole protagonist in the play, his deification as the spiritual leader as unimpeachable and infallible, indicates an earnest wish to consolidate the undemocratic form of rule "theocratic oligarchy". In times of national affliction , caused by external as well as internal threats, an escapist culture seeks refuge or an outlet in the deification of the spiritual leader, rather than rational, practical solutions. Even the Sultan, the peak of political power, in seeking salvation from El Badawy, enhances and propagates this centralization or deification of El Badawy, while the dominant culture propagates it.

$3^{\text {rd }}$ Man: I heard him [the Sultan] seeking salvation from Sidi (Master Ahmed). 


\section{Consolidation / Resistance to Democracy}

\section{in Shakespeare \& Rushdy}

$4^{\text {th }}$ Man (Astonished):Even the sultan!

Men and women echo and whisper the following words:

$1^{\text {st }}$ Woman: Even the Sultan?

$5^{\text {th }}$ Man: The Sultan also?

$1^{\text {st }}$ Man: Even the Sultan cannot be compared with Sidi Ahmed.

$2^{\text {nd }}$ Man: He changed barley to corn

$3^{\text {rd }}$ Man: When he cursed the prince, he became a beggar.

$4{ }^{\text {th }}$ Man: When he blessed the beggar ,he became a prince.

$7^{\text {th }}$ Man(in an invoking tone):Save us, Master (Sidi).

$4^{\text {th }}$ Man: Save us from our afflictions!

$1^{\text {st }}$ Woman: For the love of prophet Mohammed...

$2^{\text {nd }}$ Woman: Open your door for us...

$7^{\text {th }}$ Man: Save us! O, save us! (O !My Beloved Country, 23). ${ }^{3}$

$$
\begin{aligned}
& \text { رجل ب : أنا سمعته يطلب النجاه من سيدى أحمد } \\
& \text { رجل ؛ : (مندهشًا): حتى السلطان؟ } \\
& \text { رجل r : أنا سمعته بودنى .. كنت واقف على السلم .. } \\
& \text { تترد هذه العبارات على ألسنة الناس الواقفين رجالاً ونساءً } \\
& \text { إمرأة ا : حتى السلطان؟ } \\
& \text { رجل 0 : السلطان كمان؟ } \\
& \text { رجل ا : ويروح فين السلطان جنب سيدى أحمد } \\
& \text { رجل ب : اللى غير الشعير عمله قمح } \\
& \text { رجل r : ودعا على الأمير أصبح فقير } \\
& \text { رجل ع : ودعا للفقير صار أمير } \\
& \text { رجل V : خلصنا يا سيد (مبتهلاً) } \\
& \text { رجل ع : نجينام اللى احنا فيه }
\end{aligned}
$$

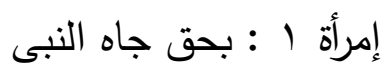

$$
\begin{aligned}
& \text { إمرأة r : تقتح لنا بابك. }
\end{aligned}
$$

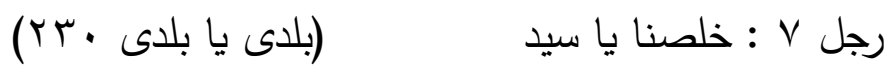




\section{Amal Aly MAZHAR}

The First Narrator explains that an escapist culture makes it acceptable for the people to endow El Badawy with supernatural powers

First Narrator: Thus, respectable gentlemen

We find that the afflicted people

Downtrodden and suffering

Throw their worries(burden) on Sidi Ahmed,

They call him "He who's invoked upon by the distressed", and "The guiding star of the downtrodden"(48-49)

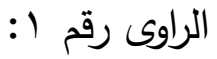

$$
\begin{aligned}
& \text { هكذا يا سادة يا كرام }
\end{aligned}
$$

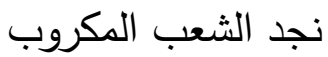

$$
\begin{aligned}
& \text { اللى كان على أمره مغلوب } \\
& \text { يرمى همومه على سيدى أحمد الإمام - ندهة المنضام - }
\end{aligned}
$$

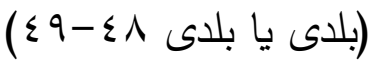

He further points out that the deification of the spiritual leader is done by his entourage or followers ,because they either fail to understand his vocation in leading the people to the right path ,or "more importantly, benefit from distorting his lessons,

First Narrator: For their main concern was to show Sidi Ahmed to the people As one performing miracles and supernatural deeds

Their aim was that people would seek him,

Wholly depend on him, leaving all their affairs in his hands, And of course between his disciples 'and followers' hands (4950)

$$
\begin{aligned}
& \text { الراوى الأول: أو - وده الأهم - من تحريفها مستقيدين. } \\
& \text { إذا كان يهههم } \\
& \text { إنهم يصوروا سيدى أحمد للناس هان }
\end{aligned}
$$




\section{Consolidation / Resistance to Democracy} in Shakespeare \& Rushdy

$$
\begin{aligned}
& \text { على أنه صاحب كرامات ومعجزات } \\
& \text { وهدفهم من كده أن الناس تلجأ إليه. } \\
& \text { وتشكل عليه وتترك أورها بين أيديه }
\end{aligned}
$$

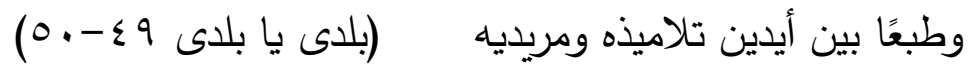

Enhancing this centralization of spiritual authority or the deification of El Badawy, the First Narrator contrasts two images of el Badawy; the real one who resists deification and the other one which is propagated by a corrupt entourage of disciples and followers for personal gain. El Kannas promises the ignorant laymen whose sons were captured in the crusade wars to set their sons free by one of his miraculous feets

El Kannas: Our master [Badawy] will set our [Muslim] prisoners free.

Another Woman: How on earth will they come back?

El Kannas: From the sky...flying!

Woman:...but the infidels have shackled them with chains

Abu Tartour: Oh,God! doesn't our master say his noon prayer in Mecca and the afternoon prayer in Egypt?

Woman: And what happens after he sets them free with his naked hands?

Abu Tartour : He'll make them fly like birds in the sky. (122123)

$$
\begin{aligned}
& \text { الكناس : مولانا حيجيب الأسرى. }
\end{aligned}
$$

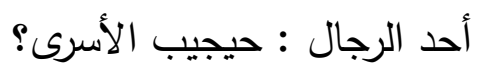

$$
\begin{aligned}
& \text { الكناس : آه مولانا حيخلص أسرى المسلمين. } \\
& \text { امرأة أخرى : وحييجوا إزاي يا سيدنا؟ } \\
& \text { الكناس : حييجوا من السماء .. طايرين (بلدى يا بلدى سب ( ) }
\end{aligned}
$$




\section{Amal Aly MAZHAR}

Other instances of propagating the deification of the spiritual leader, like the instance of the man of religion who denied the divine nature of $\mathrm{El}$ Badawy "he forgot the Holy Quran and knowledge. When he was leading people in prayer as imam he could'nt utter a single word. He madly dashed to the streets, invoking the holy saints (awleya).He remained like this until sidi Ibn 'Aqiq interceded at Sidi Ahmed El Badawy, who said on condition that he repents. He repented, so God gave him back his knowledge." (91).

$$
\begin{aligned}
& \text { استمع إلىّ .. أتعرف ما حدث لسيدي ابن اللبان .. لقد وقع فى حق } \\
& \text { سيدى أحمد ... فسلب القرآن الكريم والعلم وذهب ويصلى بالناس فلم } \\
& \text { يستطع أن يقول كلمة واحدة .. فخرج يجرى كالمجنون ... وراح } \\
& \text { يستغيث بالأولياء .. وبقى على هذه الحال أربع سنين .. إلى أن توسط } \\
& \text { لله سيدى ابن عقيق عند سيدى أحمد البدوى فقال بشرط التوبة فتاب فرد }
\end{aligned}
$$

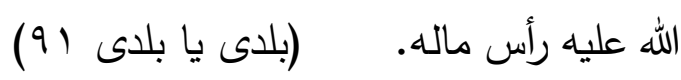

Another instance when a rich merchant refused to visit El Badawy to pay homage to him. When he ate a fish, a fish bone stuck in his throat for seven years, until he was carried to El Badawy who recited some Quranic verses, upon which the man sneezed and the fish bone came out(91).

$$
\text { أحد الرجال: (من الذين كانوا يستمعون إلى الثيخ يوسف). }
$$

والا التاجر عز الدين - تاجر التجار ـ أهل بيته كلهم راحوا يزوروا السيد

- وهو مارضيش - ليه؟ قال مش فاضى - تعرفوا حصل لله إيه ...؟

أكل سمك دخلت فى حلقه شوكة سدته - بقى لا يعرف ياكل ولا يشرب،

ولا يتكلم. قعد على الحال ده كثير؟ سبع سنين وبعدين شالوه ودوه للسيد

... قال له إقرأ عدية ياسين قرأها - عطس لـاه ل. خرجت الثوكة ...

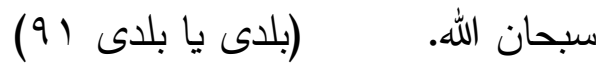




\section{Consolidation / Resistance to Democracy in Shakespeare \& Rushdy}

A woman claims that a man who objected that his women would visit El Badawy was penalized "Sidi Ahmed said I'm the one who looks after the fish and the sea monsters, I'm the performer of miracles and supernatural deeds, will not be able to protect women from men, and men from women?" (92).

$$
\begin{aligned}
& \text { 》اسيدى أحمد قال لله بقى أنا اللى بارعى الوحوش والسمك فى البحور ، } \\
& \text { أنا صاحب الكرامات والمعجزات ما أعرفش أحمى الستات من الرجالة }
\end{aligned}
$$

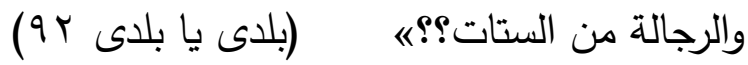

The Second Narrator, acting like a chorus who reveals the truth, explains "Of course Sidi Ahmed never said anything like that or even heard about it."(92-93)

$$
\begin{aligned}
& \text { طبعًا سيدى أحمد لا عمره/ قال حاجة من دى ولا/ سمع بيها - نهايته }
\end{aligned}
$$

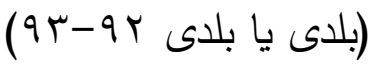

After his victory over the enchanting, fascinating woman who attempted to seduce him, Fatma bint Birry, El Badawy asserts his fallible, human nature rather than asserting his divine nature. He tells his disciples "I have always struggled to set the soul free from its prison...I am no more than a human being, just like any other human.’(123)

The centralization of authority in Badawy propagates a culture of passivity, dependency and lethargy. When a peasant complains that vagabond bedouins have robbed him of his sheep and slaughtered some of them, 'Abd El'Aal asks him not to take any action "Just go home, relax and sleep. In the morning you'll find your land evacuated from the bedouins, and your sheep returned...All your sheep will come back, both the slaughtered and the alive."(125).

$$
\begin{aligned}
& \text { عبد العال : روح أنت تام واستربح - الصبح حتلاقى أرضك سابوها العربان } \\
& \text { وغنمك رجعتلك. أنا قلت الغنم كله حيرجع لك. اللى ادبح واللى ما }
\end{aligned}
$$

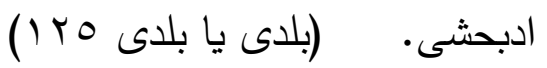




\section{Amal Aly MAZHAR}

The trenchant criticism of a culture that propagates lethargy, superstition and inactivity is deeply connected with the centralization of authority, even if it is purely spiritual.

Among El Badawy's corrupt entourage who manipulate authority for their own ends is Sheikh Fawal who represents the abuse of power by claiming to have superhuman abilities. He collects money by underhand means and quackery while El Badawy is totally unaware of that (82). Another form of the abuse of power takes a serious turn when the judge's deputies, abuse the judicial authority. Totally reluctant to accept "The Just Judge" who would jeopardize their authority, they form an "association" for "false testimonials based on perjury/They aim at building a wall between the just judge and the truth/Thus they bought the bailiff by bribery/And will buy many others in the same way."(105).

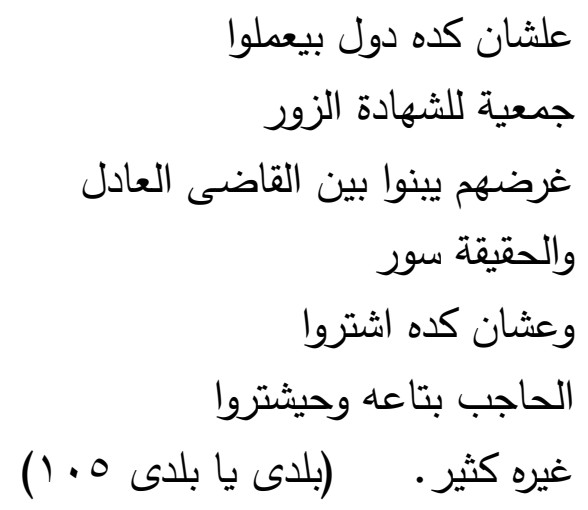

The judge's or the people's representatives further abuse their power by engaging in character assassination of their opponents, by making the honest man a thief, while the thief becomes an honest man."(152-154).Thus the bailiff cries in anguish "This is the doing of the deputies/Your deputies have slandered and damaged the reputation of people/All people have become/ perjurors and give false testimonials." (152-153) 


\section{Consolidation / Resistance to Democracy in Shakespeare \& Rushdy}

\section{Metwally: "the Angry Revolutionary" :consolidating oligarchy} or subverting it?

The play's other important figure who resists oligarchic rule, Metwally "the angry revolutionary", and "El Gharbeyaa's brave lad" as he is called, plays an important and decisive role in resisting the oligarchic system of the Mamelukes, and seeks to consolidate democracy by putting an end to political corruption. He declares "The mamelukes today are holding all major posts in the state"(160).

$$
\begin{aligned}
& \text { »المماليك النهاردة ماسكين جميع المناصب الكبرى اللى فى البلده } \\
& \text { (17 . بلدى يا بلدى (17) }
\end{aligned}
$$

Thus he issues "my orders to deny the mamelukes all state posts "and "to depose them or discharge them from their posts."(161).

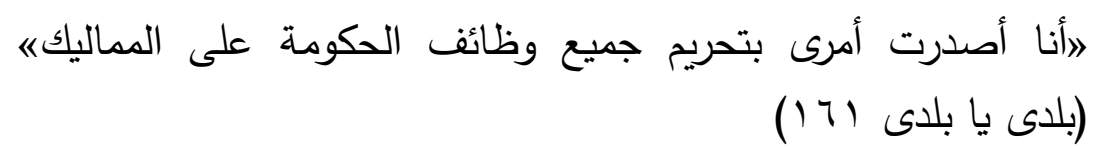

His valiant resistance of this oligarchic rule is inspired by his awareness that in defending the people's interests ,he is consolidating democracy. He tells his aide No`man who fears the power of the undemocratic Mameluki oligarchy "All the people are with you. If you help the people, they will also help you."(161)

$$
\begin{aligned}
& \text { ״الناس كلهم معاكم ... خدوا بإيدين الناس ياخدوا بإيدكمه }
\end{aligned}
$$

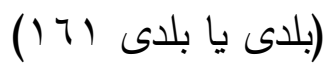

He remonstrates "when we ruled in our capacity as revolutionaries with a mission to accomplish ,how can you ask me to accomplish it today if we betray our mission and our very being. In what capacity shall we rule?"(160). He declares "We are from the people and for the people. We have not come to rule over the people. No. Anyone can rule."(136).

$$
\begin{aligned}
& \text { "إحنا من الناس وللناس. مش جايين نحكم الناس. لا ... أى واحد }
\end{aligned}
$$

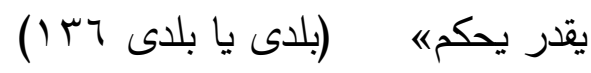




\section{Amal Aly MAZHAR}

He explains that "we've come to change the status quo/and open the doors that were locked up for years" (137).

$$
\begin{aligned}
& \text { ״إحنا جايين نغير الموجود/ نفتح الأبواب اللى مقفولة بقالها سنين" }
\end{aligned}
$$

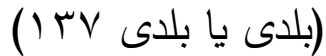

His most important pronouncement on democracy is stated in his words "It's important that we fully understand that we are not rulers, but servants/of our vocation, and in the service of right and justice."(my italics, 137)

$$
\begin{aligned}
& \text { متولى : (مستمرًا) دى رسالتا. }
\end{aligned}
$$

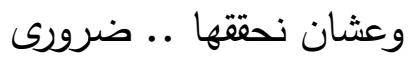

$$
\begin{aligned}
& \text { نفهم كويس .. أننا مش } \\
& \text { حكام .. انتا خدام }
\end{aligned}
$$

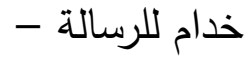

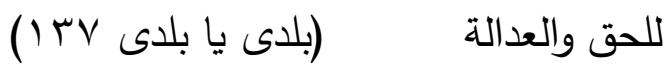

Despite his functional role as the popular hero who seeks to subvert oligarchy and consolidate the people's rule, Metwally is temporarily lured by the temptation of political authority. He is rebuked by El Badawy who shuns all forms of authority. "The Angry Revolutionary now sits in the minister's chair? This is beyond all comprehension!"(84)

$$
\begin{aligned}
& \text { 》الثائر الغضبان الآن يجلس فى كرسى الوزارة. هذا شىء لا أفههه《 }
\end{aligned}
$$

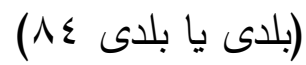

When Metwally attempts to explain and justify that he did so after ridding the state of the corrupt Armenian minister, El Badawy hurls his invectives over him "You're worse than him...because when Bohram took this post, he did not sacrifice anything. But you have given up everything. Even your very being... Where is your anger? Where's your rage? Have you put an end to Bohram to rule instead of him? ... What justice are you 


\section{Consolidation / Resistance to Democracy in Shakespeare \& Rushdy}

talking about when the Tartars, the Mamelukes and the infidels are ruling with you over the people?"(85)

$$
\begin{aligned}
& \text { السيد : لأن بهرام لم يتخلى عن شىء عندما أخذ الحكم .. أما أنت } \\
& \text { فقد تخليت عن كل شىء .. تخليت عن كيانك ماذا أنت الآن؟ } \\
& \text { متولى : إنى مازلت كما أنا - الثائر الغضبان. } \\
& \text { السيد : أين غضبك؟ إنك أطحت برأس بهرام لتحكم بدلاً منه؟ } \\
& \text { متولى : ولكنى أحكم الناس بالعدل. } \\
& \text { السيد : أى عدل يمكن أن يكون والتتار والمماليك والكفار يحكمون }
\end{aligned}
$$

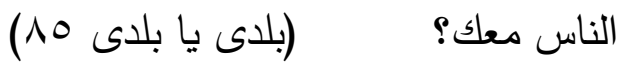

The temporary temptation of political authority that Metwally falls a prey to thus jeopardizes his role of the defender of the people's interests.

Metwally is fully conscious of his role in inspiring the people. When the people shun him as a representative of an undemocratic authority ,as he is later confronted by this "The people say that you yourself have become a mameluke"(210)

$$
\text { 》الناس بتقول أنك أنت كمان بقيت مملوكه (بلدى يا بلدى · (Y) }
$$

and thus do not seek his help, he instantly goes to them "If the people don't want to come to me, I'll go and seek them" (207).

$$
\begin{aligned}
& \text { "إذا كانت الناس مش عاوزة تيجى لى أنا حاروح للناس" }
\end{aligned}
$$

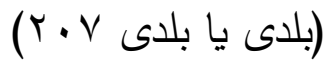

The tragic irony that confronts Metwally is that having put an end to the Mameluki oligarchic rule, he is faced with one which is more trenchant; the oligarchy of his entourage and followers who enjoy absolute authority which he is not aware of. He is confronted by the common man

Metwally: You have to understand the situation properly .As for the 


\section{Amal Aly MAZHAR}

Mamelukes I ordered that they would be deposed instantly from all their posts.

Kholousy: And what about your men? Have you deposed your own rulers as well?

Metwally: Why should I depose my men? I'm saying I deposed the Mamelukes.

Kholousy: And Sa'faan bey,and Luqman bey,and No'man bey and Soliman bey, aren't they all mamelukes?(209)

$$
\begin{aligned}
& \text { متولى : أنتم ضرورى تفهما الوضع كويس .. بالنسبة للمماليك أنا أمرت بعزلهم } \\
& \text { من جميع الوظائف ... } \\
& \text { خلوصى : ورجالتك! الحكام بتوعك عزلتهم هم الآخرين. } \\
& \text { متولى : وأعزل رجالتى ليه. أنا باقول عزلت التوالت المماليك. } \\
& \text { خلوصى : وسعفان بيه ولقمان بياه ونعمان بيه وسليمان بيه ماهمش مماليك }
\end{aligned}
$$

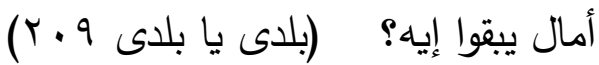

Tragically, the popular imagination transforms the former national hero who attempted to subvert oligarchy and consolidate the people's rule into a member of the new oligarchy, a fact which induces the people to accuse him of having become a mameluke himself.

Metwally: I'm no longer what I once was. You think that I'm still Metwally the angry revolutionary. But no, master! You're deluded. I'm nothing but a ruler, just like all other rulers. A mean mameluke in the Sultan's entourage.

I've ruled so I became like all the other rulers,

My free revolutionary men have become mameluki princes. We came to destroy the serpents, but we became serpents gulping up the people. Can we blame the people if they think that I've become like my men.(219) 


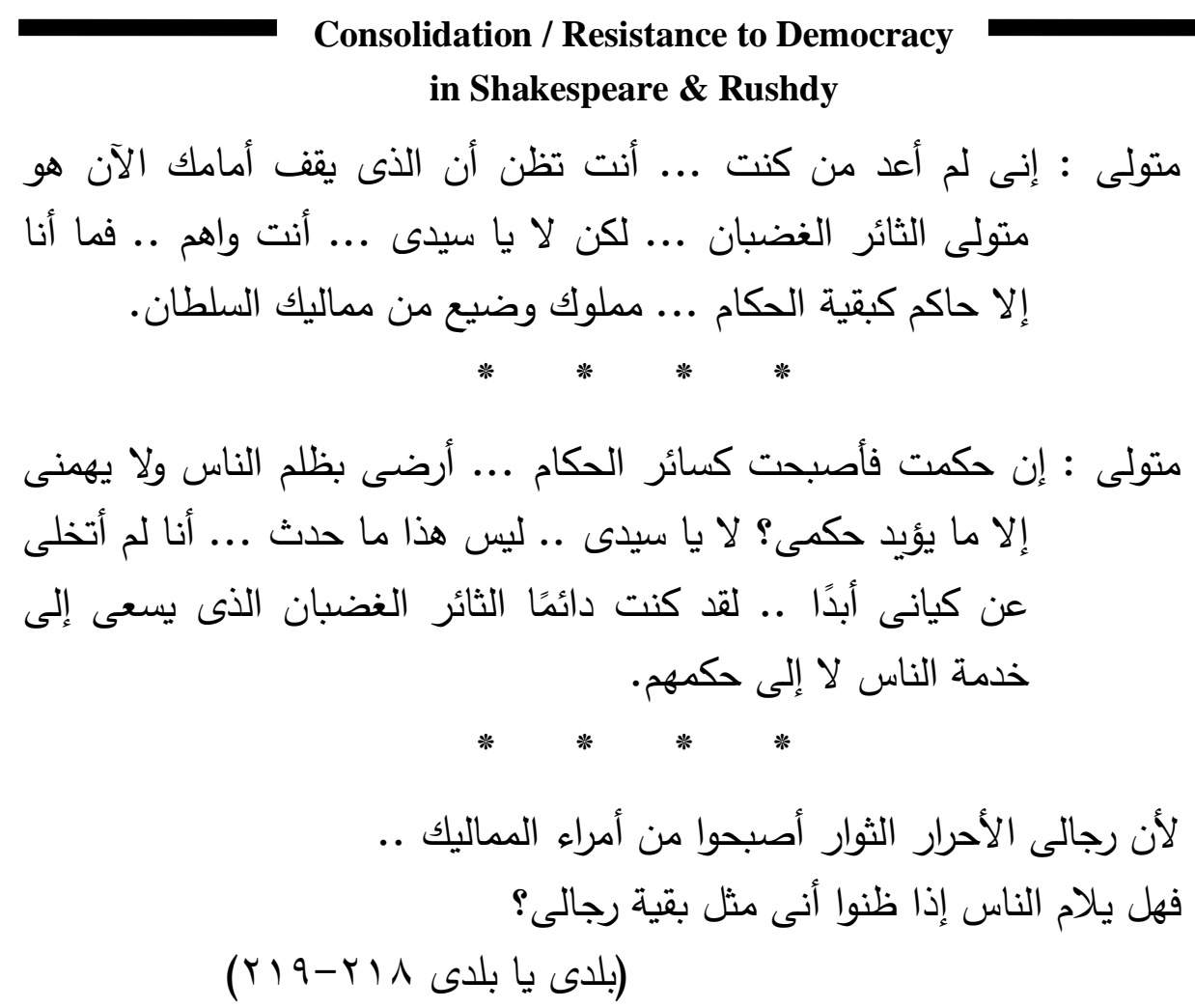

The resistance to different forms of unitary, undemocratic authority gains momentum since it is performed by those who could profit most by it: El Badawy and his disciple Metwally. Military oligarchy is both represented, and resisted by, Metwally, while El Badawy resists the people's deification of him, since it symbolizes for him a form of absolute spiritual authority which disables the people and makes them resort to lethargy and superstitions and become wholly dependent on him .In the temptation scene, even when Fatma Bint Birry, the fascinating woman who seduced a great number of men of religion realizes El Badawy's great spiritual selflessness, immediately prostrates herself in front of him, he asserts his human nature by reprimanding her "You only prostrate yourself to God"(114)

$$
\text { 》السجود الله فقط" (بلدى يا بلدى ع 1 ( ) }
$$




\section{Amal Aly MAZHAR}

and when she asks him to grant her salvation that "salvation is by God's hands only"(121). His words "I feel now that I can walk on water"(117) is not meant to assert his divine, superhuman nature, but rather that he has as a sophist, overcome and transcended his human frailities. Self-liberated from all worldly concerns , he believes "No one can coerce you to do anything except if you wish it yourself"(118)

$$
\begin{aligned}
& \text { ״لا أحد يملك أن يغلبك على أمرك إلا إذا رضيت أنته }
\end{aligned}
$$

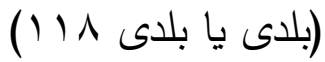

and "absolute power of the will can overcome and transcend all forms of slavery.”(119)

While the people seek to centralize power in El Badawy by respresenting him as divine with infinite,superhuman abilities ,El Badawy staunchly resists it. El Badwy plays the highly crucial role of awakening the people to resist both the Mameluke's oppression and the external threat of the Crusades. He declares "There has to be a hand which takes the people by their hands to help them to find their way and guide them."(177).

$$
\begin{aligned}
& \text { "الابد من يد تأخذ بيد الناس وتساعدهم على السير "17 } \\
& \text { ( بلدى يا بلدى VVV) }
\end{aligned}
$$

For him sophism is not an escapist act of shunning worldly matters, but rather an act of self-emancipation "He who can liberate himself can liberate others"(179).

$$
\begin{aligned}
& \text { 》ن استطاع أن يحرر نفسه هو الذى يستطيع أن يحرر غيره" }
\end{aligned}
$$

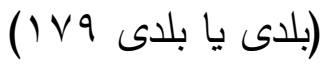

His ultimate goal is to make the people aware of their rights and responsibilities by setting them free from slavery(180). By resisting "spiritual absolutism" he takes one further step when he urges his followers 


\section{Consolidation / Resistance to Democracy in Shakespeare \& Rushdy}

(El Settouheyyein) "to urge all free men to join Metwally in liberating the people"(181).

$$
\text { 》ادعو الأحرار فى كل مكان إلى الجهاد مع متولى" }
$$

Despite his terminal illness, El Badawy performs a highly important function in instigating the people to resist oppression. However, as the dominant culture of lethargy and dependency prevails, it puts an end to his efforts as the Narrator points out (188-189) the people fall into trances of passive behavior and fail to resist oppression. The opening scene which portrays El Badawy's Mulid or Festival one hundred years after his death indicates only too clearly that a much-rejected culture of dependency and a state of spiritual and intellectual trance still persists in modern times. Ironically, while El Badawy resists the theocracy of the spiritual leader being sacrosanct and sham hero worship, the dominant culture encourages and maintains it. Commenting on the two temporal levels in the play, Hammouda perceptively believes "as if History were repeating itself" (205).

A New Historicist reading of the play would reveal that such notions as El Badawy's deification, a form of "spiritual absolutism" which he firmly rejects and negates, since it enhances and consolidates undemocratic practices subtly reflects acts of deification of the head of the state at the time which was propagated by " interest groups" who benefitted most by it. It is interesting to read that "the Egyptian political system was characterized by extreme centralization in the formation of the state apparatus, until it reached the peak of the hierarchy represented in the president of the Republic"(El Bishry,24) and that "Authority was centralized in the president, who was entitled, according to the constitution, to infinite authorities"(El Bishry, 25) With his perceptive vision, late president Anwar El Sadat could draw the parallelism between the deified Badawy in the 12th century and the deified head of state at the 


\section{Amal Aly MAZHAR}

time, which Rushdy justified as such "Even if my conscious mind lays the blame of the defeat on "Abd El Nasser, since the defeat happened during his rule, my subconscious mind refuses this, testified by my play $O, M y$ Beloved Country! late in 1967.Its symbolic protagonist was El Sayed El Badawy who symbolizes the leader and the mentor who lived all his life teaching his disciples how to carry on with his vocation"(Rushdy,1987). However, despite this flimsy defense, historical facts belie this. Renowned historian 'Abdel 'Azeem Ramadan, a once ardent believer in the Nasserite regime, states in The Demolition of Gods "My objectives have never been to attack any military or political leader but were much nobler than that...and that is to demolish hero-worship, a practice which is usually established by totalitarian regimes"(14) and that "my goals were to demolish such regimes that led to, and caused the 1967 defeat" (Ramadan,15) The absence of a democratic system of government which led to hero-worship is attested by the field of political analysis, in the book entitled The Development of Democracy in Egypt mentions that "Egypt in that period[from 1952-1970] lived long without an elected parliament for nine whole years it lived without a parliament such as the period from 1961-1964" (Hilal,1986,261)This accounts for the fact that after the June 1967 defeat and the subsequent crisis that the regime confronted, one which was reflected in the students' and workers' demonstrations which called for political freedom, the regime adopted the motto "the open society" as a signal towards more democracy (Hilal,1986,260)

The criticism of the rejected Mameluki "military oligarchy" does not pertain to El Badawy's 12th century Egypt, but more tragically, to a modern ,post- 1967 Egypt .El Malwany's repeated anguished cry that "half of the house has collapsed...the rest will follow" and "O, countrymen, listen, listen! the house will collapse with everyone inside it. All will die, those who destroyed it and those who didn't. Beware, beware!'(210) 


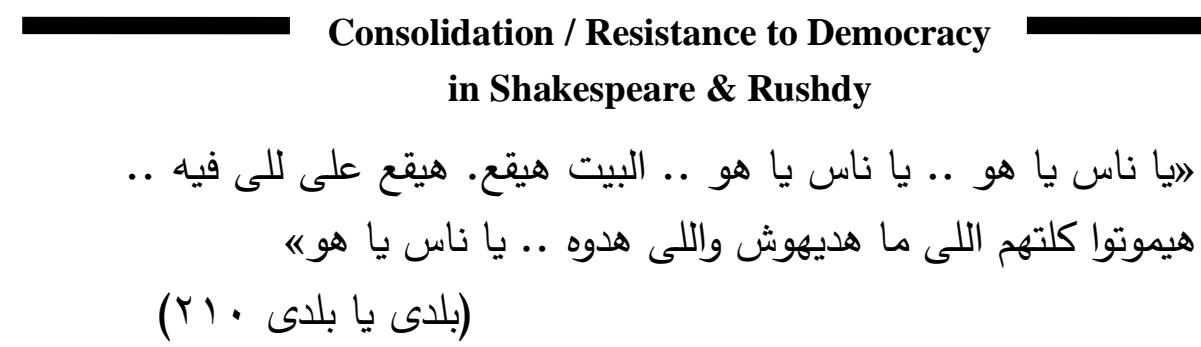

acts as a refrain uttered by the ageless, Tiresias-like clairvoyant to both mourn the traumatic consequences that befell Egypt and warn of more to be expected . "The military oligarchy" which ruled in post 1952-Egypt, led to devastating consequences, both internally and externally. The 12th century Crusades referred to in the play, find their realistic counterpart in Israeli occupation of one third of Egypt after the 1967 devastating defeat. In a perceptive remark made by 'Abdel Latif El Baghdady, former member of the 1952 military Council, and Nasser's ex-vice president he links the vices and some faulty practices of the military oligarchy which led to 1967 defeat "Maybe through the traumatic 1967 defeat, God wanted us to shed off our inadvertence and demolish the Gods."(El Baghdagy,290).

The relevance of analyzing or reading the two plays under study from a New Historicist perspective is best expressed in the following "The aim is not to represent the past as it really was, but to present a new reality by resituating it" Shakespeare's Coriolanus and Rashad Rushdy's $O, M y$ Beloved Country! show different forms of consolidating/resisting democracy. To my belief, Coriolanus was an implicit warning directed to the undemocratic monarch James I against his violation of democracy, one which ultimately led to the first bloody revolution when his successor, Charles I was beheaded. Rushdy's O,Beloved Country! conveys an implicit criticism of the undemocratic military oligarchy at the time that the consolidation of democracy by El Badway when he refuses a monolithic spiritual rule could be the safety valve to a whole nation. However, despite the implicit criticism and warnings embedded in these two plays Santyana's words hold true, since those who do not learn from history repeat the same mistakes over and over again. 


\section{Amal Aly MAZHAR}

\section{Endnotes}

It is interesting to read that

1- "The class struggles of the Roman Republic resulted in an unusual mixture of democracy and oligarchy the word republic comes from the Latin res publica which literally translates to public business. Roman laws traditionally could only be passed by a vote of the Popular assembly (Comitia Tributa). Likewise, candidates for public positions had to run for election by the people. However, in the Republic, the Roman Senate represented an oligarchic institution, which acted as an advisory body.

In the Republic, the Senate held great authority, but no actual legislative power...However , as the Senators were individually very influential, it was difficult to accomplish anything against the collective will of the Senators of the Roman Republic" http://en.wikipedia.org/wiki/Democratic_elements_of_Roman_Republic,10/25/2010, p1-2)

2- The quotation occurs in The Political Works Of James I, reprinted from the edition of 1616, ed Charles M. Mcllwain (New York: Russel and Russel,1965), p.43

3- All translations from Arabic into English, including the play under study are done by the present author.

\section{Bibliography}

Cahn, Victor L. 1996. Shakespeare the Playwright :A Companion to The Complete Tragedies, Histories, Comedies and Romances. Praeger.

Cohen, Walter and Weimann, Robert. 1992."Marxism and Materialism : Aristocratic Failure" in Shakespearean Tragedy. ed. and intro. by John Drakakis. Longman

El Bishry,Tareq.1987 Democracy and Nasserism. Shorouq Bookshop.

$$
\text { طارق البشرى } 19 \text { 1 الديمراطية والناصرية. مكتبة الثروق. }
$$

Hammouda, Abd El Aziz. 1972. The Drama of Rashad Rushdy. AngloEgyptian Bookshop.

$$
\text { عبد العزيز حمودة } 19 \text { ا مسرح رشاد رشدى، مكتبة الأنجلو المصرية. }
$$

Hilal, 'Aly El Din.(ed)1986.The Development of Democracy in Egypt. Nahdet El Sharq Bookshop.

$$
\text { على الدين هلال(تحرير) ب191 اـ تطور الديمقراطية فى مصر . مكتبة نهضة الشرق. }
$$




\section{Consolidation / Resistance to Democracy} in Shakespeare \& Rushdy

Kristeva, Julia, Andree Green and Janet Adelman. 1992. “'Anger's My Meat': Feeding, Dependency, and Aggression in Coriolanus" in Shakespearean Tragedy. ed. and intro. by John Drakakis. Longman

Montrose, Louis A. 1989. "Professing the Renaissance: The Poetics ofCulture", in H. Aram Veeser ed. The New Historicism. Routledge.

Ramadan, Abdul Azim.1985. The Demolition of Gods :The Story of 1967 June War. Madbouli Bookshop

عبد العظيم رمضان 910 ـتحطيم الآلهة: قصة حرب يونيو 97 19 ـ مكتبة مدبولى.

Rushdy, Rashad. n.d. O, Beloved Country. Anglo-Egyptian Bookshop

$$
\text { رشاد رشدى. د.ت. بلدي يا بلدى. مكتبة الأنجلو المصرية. }
$$

Rushdy, Rashad.1987. "The mentor and the lover" by Thoraya Rushdy. Rashad Rushdy. State Publishing House(GEBO).

ثريا رشدى. 19 NV 》المعلم والعاشقة《، رشاد رشدي. الهيئة العامة للكتاب.

Shakespeare, William.1995.Coriolanus .The Complete Works of Shakespeare. Oxford University Press.

Tennenhouse, Leonard. 1994. "Strategies of State and political plays: A Midsummer Night's Dream, Henry IV, Henry V, Henry VIII." in Political Shakespeare: Essays in Cultural Materialism. ed Jonathan Dollimore \&Alan Sinfield. Manchester University Press. 